Studia Anglica Posnaniensia 48/4, 2013

doi: 10.2478/stap-2013-0014

\title{
LITERATURE
}

\section{“MUCH, I AM SURE, DEPENDS ON YOU": JAMES FORDYCE'S LESSONS ON FEMALE HAPPINESS AND PERFECTION}

\author{
KATARZYNA BRONK
}

Faculty of English, Adam Mickiewicz University in Poznań

\begin{abstract}
Conduct literature written for women has had a long tradition in British culture. According to scholars, such as Ingrid H. Tague (2002), it circulated most widely during the eighteenth century because new ideals of proper feminine behaviour and conduct developed. The Scottish Presbyterian minister and poet, James Fordyce (1720-1796), very observant of the transformations in his society as well as advocating the need to reform moral manners, likewise created a set of sermons dedicated to young women of the second half of the eighteenth century. He is worthy of close study not only because his Sermons to Young Women constitute an important yet understudied contribution to the tradition of conduct writing, but also because he records and disseminates opinions on female perfection both as a man of the church as well as the representative of his sex, thus presenting a broad scope of the official gender ideology of the eighteenth century. The proposed article engages in a close reading of Fordyce's rules and regulations pertaining to proper femininity, pointing also to the tone of his published sermon-manual and the socio-techniques used for the sake of perpetuating his ideological precepts for women. As such, the article is to prove that this popular eighteenth-century preacher, whose work was even mentioned on the pages of Jane Austen's Pride and Prejudice, not only offers a significant contribution to ongoing research on conduct manual tradition as well as on feminist re-readings of women's history, but also adds more evidence to feminist claims of a purposeful campaign aimed at creating a selfaware and self-vigilant woman who almost consciously strives to become the object of masculine desire, and allegedly all for her own good.
\end{abstract}

Keywords: Fordyce, conduct text, femininity, patriarchy

The eighteenth century is remembered for its economic, political and cultural progress. Literary scholars investigate the period in search of the foundations of sentimentalism or sensibility, and discuss this philosophical trend's links to the "cult of feeling, a cult of melancholy, a cult of distress, a cult of refined emotionalism, a cult of benevolence" (Barker-Benfield 1996: xix), which, due to the asso- 
ciation of all these features with femininity, leads them to focus more attention on women's role and representation in life and literature. Feminist historians add to this a re-evaluation or even a re-discovery of women as subjects and, finally, as authors, although Karen O'Brien (2010: 2) herself cautions that this does not mean that eighteenth-century "investigation[s] of human sociability and the historicizing of women were in themselves hospitable to what we would now call feminism". Indeed, other scholars (i.e. Tague 2002) remind us of the development of the idea of separate, gendered spheres during the Long Eighteenth Century and an even more restrictive enclosure and control of women within the private sphere. Those sharing this negative opinion on the positioning and value of the female sex in the eighteenth century notice that this is also the century that created many volumes of advice literature for women, offering it in novels but also presenting conduct lessons in pamphlets, sermons, essays and treatises. Vivien Jones (1995: v), for instance, states that "conduct literature, particularly for women, was a growth industry during the eighteenth century" as this was one of the ideological ways "of reconciling women to domestic, deferential position", as she adds elsewhere (Jones 1997: 10). In these para- and literary narratives, women were told what it means to be a woman, and they were advised how to embody and perform the best version of femininity. These ideals were founded on masculine paradigms of propriety or perfection because the majority of conduct writers were men. They took upon themselves the role to admonish, chastise and guide women in their everyday conduct, stressing that their suggestions are designed not only for the benefit of all, but, most importantly, for the sake of women's personal happiness. While sentimental novels (Samuel Richardson's Pamela or Virtue Rewarded) fictionalized paragons of virtue and showed the consequences of misbehaviour, non-fictional conduct texts offered more practical advice on manners, every day practices and rules of polite comportment. James Fordyce, whose Sermons to Young Women (1766) ${ }^{1}$ are analyzed in the present article, offers exactly that - a set of rules of conduct which are to make the young woman desirable in the eyes of God, society, and in particular, its men.

There are many definitions of texts of conduct but Sarah E. Newton (1994: 4) summarizes the key points repeated by other scholars best when she states that "[a] conduct book is a text that is intended for an inexperienced young adult or other youthful reader, that defines an ethical, Christian-based code of behavior, and that normally includes gender role definition". She further adds that they help with "codyfing society's idealized expectations" in respect to proper

In this article I am using two different editions of Fordyce's sermons. Quotes from Sermons I to $V I$ and the Preface are from volume I, the $6^{\text {th }}$ London edition (1766), while VII to XIV and the Conclusion are found in volume $2,6^{\text {th }}$ Dublin edition (1767). Some sources suggest that the volumes were initially published in 1765 , yet others indicate it was 1766 . The latter is the most repeated one, hence its inclusion in the article. 
comportment in life (Newton 1994: 4). While, for many reasons, including literacy, they were not read by everyone, those who had access to such roleteaching narratives in print could treat them as guidebooks or, as Jones (1995: vi) convincingly argues, conduct books were "guides to success - and survival". These two benefits seem particularly significant in the reality of the eighteenthcentury, considering all the changes that societies across Europe and in America were experiencing. With the rise of the new middle classes, the struggle for survival of the affluent upper classes, and an ever growing distrust, if not hostility, towards the aristocracy, people felt the need to re-define themselves as members of their particular social groups and formulate the rules of social interaction within and without their classes.

The eighteenth century is, therefore, also important in terms of the introduction of the word and idea of etiquette. Jorge Arditi (1998: 1-3), in The Genealogy of Manners, describes the civilisational progress from courtesy to civility and, finally, to etiquette, which was subsequently expanding its meaning to finally denote the rules of individual behaviour which should be observed in all interactions with "polite society". The historian further suggests that manners are "ideal vehicles" for analysing the origins and transformations of what he calls the "infrastructures of social relations" (Arditi 1998: 13). To understand manners, as Arditi seems to suggests, is to engage in a daunting and very multifaceted study of various practices that help societies establish the foundations of similarities and differences between individuals, groups (classes, sexes, religions) and, finally, nations. While such an all encompassing task of cultural research is beyond the scope of this article, the subsequent analysis of James Fordyce's sermons, which serve as a printed conduct manual, ${ }^{2}$ will help to distil some of the eighteenth-century sets of ideas and ideals concerning the rules of conduct propriety or even perfection in behaviour for women.

Although Fordyce - a popular Scottish preacher who eventually moved to London and gained a faithful audience among his parishioners, and was even, allegedly, admired by David Garrick himself, ${ }^{3}$ - was concerned with virtue and conduct of all Christians, the present article will focus solely on his lessons on

2 Fordyce's other publications include, for instance, "The Eloquence of the Pulpit, an Ordination Sermon, to which is Added a Charge", $12 \mathrm{mo}$ (1752), "The Temple of Virtue, a Dream" $12 \mathrm{mo}$ (1747), $2^{\text {nd }}$ edn. (1755), "The Folly, Infamy, and Misery of Unlawful Pleasures," a sermon preached before the general assembly of the Church of Scotland, $25^{\text {th }}$ May, 1760, 8vo (1760) and Addresses to Young Men, 2 vols. $12 \mathrm{mo}$ (1777).

3 What is known about James Fordyce is best presented at http://spenserians.cath.vt.edu/Au thorRecord.php?\&method=GET\&recordid=1179. This biographical database likewise offers two obituaries, one from the eighteenth and the other from the nineteenth century, which prove how popular and liked the preacher was. What adds to his fame is also the fact that his Sermons feature in Jane Austen's Pride and Prejudice. For the significance on this scene in the context of the novel, see: http://www.jasna.org/persuasions/on-line/vol34nol/ford.html. 
proper femininity, thus limiting the aforementioned infrastructure to relations between women and men, and women and society. ${ }^{4}$ This is partially motivated by Arditi's (1998: 14) opinion that "[a]n infrastructure of social relations is not supposed to be representative of an entire population" because it presents "the positivities of the dominant classes alone", which suggests, naturally, that the normative ideology is instilled, promoted and maintained by the representatives of groups in power. As such, Fordyce not only speaks from the position of a clergyman, wielding the authority given to this particular social status, but, importantly, he also speaks as the representative of his own sex and aims his pieces of advice and admonitions at groups of less influential, one may also risk saying powerless, individuals, namely women. This positioning of the speaker is quite typical within the tradition of conduct manuals as men constitute the predominant group of conduct writers in all literary and historical periods up to the Victorian times. By custom and in practice of patriarchal cultures, they have been given the right to study, meticulously analyse, judge, police and chastise their inferiors (women, servants, children). While showing how these prerogatives were used by Fordyce, the present article will subsequently immerse in the lessons on female perfection and happiness created by the preacher.

As the history of conduct writing indicates, men were using but also abusing this ideological privilege to teach, judge and monitor. From vitriolic attacks on the female sex during the early modern querelle des femmes (discussions on "the Woman's Question/Quarrel"), through more "polite" suggestions and admonitions of the narratives in later periods, to straightforwardly stated rules and regulations designed for women, male authors managed to create seemingly heterogenous models of perfect femininity. Indeed, they only seem different from one another or period-specific because a more thorough and diachronic study of conduct writing for women indicates that "conduct writers argue that an absolute, virtually unchanging and unchallengeable standard of ideal behavior does exist and may - indeed must - be achieved" (Newton 1994: 4). Jones (1995: viii) further adds that judging by these texts of comportment "femininity is natural, inescapable, and transhistorical". To these sets of features and rules women were expected to adhere, while being threatened with various forms of contempt, ostracism, exclusion and downright violent mistreatment in a few well publicised cases, if they did not. As such, the masculine prerogative to fashion and evaluate proper or ideal femininity created "a woman who was constantly aware of the fact that she was a woman, one who never stopped checking her behavior and thoughts against standards of ideal womanhood" (Tague

Due to its focus on the two volumes of the sermons, the present article does not refer to Fordyce's The Character and Conduct of the Female Sex, and the Advantages to be Derived by Young Men from the Society of Virtuous Women. A Discourse (1776). 
2002: 22). These standards are considered oppressive by feminist scholars because they not only regulate the patterns of proper behaviour according to masculine imagination but also often suggest that they are impossible to achieve. Margaret R. Miles (1991: 139) states:

\begin{abstract}
'[p]ositive' images of women - that is, images of socially approved women, 'good' women from the perspective of the governing male collective - often function not as 'rewards' for women, but as prescriptive messages. Positive images define what female 'goodness' looks like and urge women to imitate the qualities of these images. Positive images of women, then, play a very important role, even or especially, in the most misogynist societies. Similarly, misogynist literature consistently pictures and praises good women; frequently an unrealistically inflated sense of women's superiority justifies the author's attack on women who fall from this ideal as most women inevitably must.
\end{abstract}

Unsurprisingly, then, women were likewise made aware of the consequences of any type of transgression of the rights and obligations given or enforced on them. While, naturally, one needs to distinguish between words and deeds, or ideological precepts and actual life, conduct texts pose as a powerful ideological tool for social, religious and even medical governance of women.

While Fordyce would probably never himself publically acknowledge the fact that his lessons are part and parcel of any ideological enforcement practice, in essence, his sermons are exactly that. Sermons to Young Women, despite its clear religious overtones and with its general purpose of teaching Christian precepts, reveals the "concern" of all eighteenth-century manuals of comportment in that it shows "how women might create themselves as objects of male desire" (Jones 1997: 14). This identity formation mission of conduct texts in the eighteenth century has been widely discussed by Nancy Armstrong and Leonard Tannenhouse, the editors of The Ideology of Conduct: Essays in Literature and the History of Sexuality, who stress that the purpose of such narratives was to present to a general audience the features which they should both assimilate (lessons for women) and additionally expect in others (lessons for men). While Fordyce claims that his collections of sermons are the result of "an unrefined regard for the Female Sex" (Fordyce, Preface, 5), the pieces of advice he offers consistently hint at creating women as objects of desire, that is perfect women, perfect companions for men and perfect British citizens (without all the political rights, of course).

As an acute observer of his times and all the socio-cultural changes in the eighteenth century, in his sermons Fordyce justifies his reason for the necessity of conduct manuals in general. He complains that the world is addicted to ostentation (Fordyce, Sermon II, 38) and he openly bemoans "seeing the effeminate, trifling, and dissolute character of the age reformed" (Fordyce, Sermon I, 20), 
which in reality is "nourished by dissipation" (Fordyce, Sermon IV, 69). However, since this is a narrative devoted to women, he focuses more on the nature and comportment of the fairer sex. Complaining on the processes of socialisation gone wrong in his times, he describes how easily women can be spoiled:

\footnotetext{
Their curiosity takes fire; they are eager to participate [in diversions]. They are indulged once, a second, a third time, often without controul. ... Their ears are wounded by the language of vice ... . But custom soon begets familiarity; and familiarity produces indifference. ... And now they seldom blush ... . At the image of sin they tremble no longer - their minds are already debauched. All internal fences of modesty are broke down.
}

(Fordyce, Sermon III, 48, spelling original)

In fact, it is allegedly so bad that he finds it difficult to find women who even dare "to be superior to the follies of [their] sex?" (Fordyce, Conclusion, 219). He blames not only all the temptations of the refined age for this degeneration of the female character, but also the parents who allow their daughters to indulge in all the pleasures that the new socio-economic situation enables and generates. Tague (2002: 9-10) confirms that one of the concerns of the eighteenth century was the fact that more women were openly (or shamelessly) benefiting from the "new financial practises", and her research suggests that they were very visible in this emerging world of consumption. Her generalized term for them is "Women of Quality", which suggests that this phenomenon pertained to a particular social strata. However, Fordyce sees the ubiquity of fashionable women as a more encompassing problem. As a consequence, he claims to have designed his sermons for women of all conditions and ages.

Another thing that Fordyce is aware of and preaches in his sermons is the importance of women. While Amanda Vickery (1999: 93) proves that the praise of women and their "natural" virtue cannot be limited to the eighteenth century, she does notice the tendency to idealize women in this period. Fordyce concurs and he uses praise as one of his socialising socio-techniques. Vowing honesty, required of him due to his profession and guaranteed by the very nature of his personal character, he bombards his readers and listeners with such hortatory statements as: "He that has a true taste of happiness will choose for his own sake, to cherish the kindest opinion of the female destination" (Fordyce, Sermon $V I I, 96)$ and "Much, I am sure, depends on you" (Fordyce, Sermon I, 14). Like authors of conduct texts before and after him, he convinces women of their indispensability and importance in ensuring the well-being not only of families but even, more generally, of the entire society. They have the power to influence others because of their innate virtue, and thus they may serve as paragons to emulate. To add to such bombastic statements, he likewise stresses that they are absolutely necessary to the reformation of the male sex. At one point he 
insists: "The influence of the sexes is no doubt, reciprocal; but I must be of opinion that yours [women, KB] is greatest. ... Those that are most conversant with women of virtue and understanding will be always found most amiable characters ..." (Fordyce, Sermon I, 19). As such, he convinces women that they have agency in promoting the reformation of manners of men, and, therefore, their proper conduct is indispensable in the creation of a glorious nation.

To add more emphasis to his arguments he not only presents his own opinion on women, and stresses how much he differs from those disrespecting them, but Fordyce also attempts to put the record straight about the value of women. As such, he places himself in opposition to those who engage in antifemale disputes, even if only for the sake of fun or banter. He states:

\begin{abstract}
The frailty of women has been frequently a topic of triumphant declamation. On this subject much unkind wit has been displayed; and many dull sarcasm is daily added, and widely circulated, with an air of conscious satisfaction. Hardly can one go into a company of men, where licentiousness of tongue passes for freedom of conversation, without hearing poor women abused for their worthlessness, or weakness, or both.
\end{abstract}

(Fordyce, Sermon IX, 37)

Evaluating such a fashionable type of wit, he judges such exponents of female worthlessness as "unkind to society", ones that cannot discriminate between a few "foolish and vicious women" (Fordyce, Sermon I, 14) and the rest who should be appreciated and praised. Foreseeing possible disagreement of the same wits, he explains that the repeated pronouncement of women as "weaker vessels", this essentialist categorisation has been misunderstood. For Fordyce, this alleged weakness denotes something more positive: "those vessels are so styled, which being of finer materials, or more delicate construction, and therefore easily broken or hurt, are for that reason, and for the regard also which people have for them, used with particular tenderness" (Fordyce, Sermon IX, 39). While, of course, a contemporary scholar of conduct tradition must see such arguments as being just as deprecating as any other vitriolic anti-women account, Fordyce simply follows the trend of eighteenth-century moralists who tried to persuade women to accept their imperfect (in comparison to men) nature and discover the values/benefits of a situation they cannot change. Vickery (1999: 69) confirms such interpretation by saying that "[t]he language of feeling ... was pregnant with allusions to tender mastery and pleasurable surrender". Earlier in her The Gentleman's Daughter, she claims that women themselves told each other to "bow to the will of providence" (Vickery 1999: 8), so Fordyce's line of argumentation would have probably appealed to them.

Perhaps sensing that his excessive, though ambiguous, praise might sound false, or at least suspicious, Fordyce assures in his sermons that he does not use 
flattery to seduce his readers and listeners. Newton (1994: 8) would probably disagree as she sees the success of conduct texts in the fact that they attempt to allure readers to proper behaviour. Fordyce, however, insists throughout his sermons that his are simply "faithful and candid admonitions" (Fordyce, Sermon $I, 13)$, and he is speaking as a friend whose duty it is to tell women the truth about the world and their positioning within it. On flattery the listeners/readers should not count: "You will not look for it here ... If anything should appear harsh, be assured it proceeds from real regard" (Fordyce, Sermon $I, 13)$. This regard is progressively stressed and established with every sermon, which is visible in what needs to be called terms of endearment which he uses. He addresses women with phrases such as: "my fair hearers", "my fair countrywomen", "ye daughters of Britain" (Fordyce, Sermon I, 18-26); "my dear Clients", "my young friends" (Fordyce, Sermon II, 28-42); "my honoured hearers", "my sisters" (Fordyce, Sermon III, 44-57); "my beloved pupils" (Fordyce, Sermon VIII, 18); "my Christian friends" (Fordyce, Sermon IX, 63); and "my dear charge" (Fordyce, Sermon XIV, 187). As such, he then claims not only the position of a preacher to his sisters and daughters in faith but also of a fellow Briton, a brother and a father. ${ }^{5}$ This is then followed by his promise of delivering only "by sentiment, persuasion, and the native influence of fraternal counsel" (Fordyce, Sermon $I V, 62)$. More importantly, however, he introduces himself as a man, the representative of his own sex. Therefore, he is not only calling for the reformation of the female-kind for the well-being of Britain in general, but also on behalf on other men. Fordyce rather straightforwardly admits: "It is natural for me to wish well to my own sex; and therefore you will not wonder, if I am felicitous for your possessing every quality that can render you agreeable companions" (Fordyce, Sermon I, 24). In view of such comments, his promises of helping women to awaken their naturally virtuous potential so that they can "act up to the best of standard of [their] sex" (Fordyce, Sermon I, 14) seem less selfless than he initially suggested.

One may hold this against Fordyce, but after reading both volumes of the Sermons one notices that such male-oriented focus of his suggestions may actually be one of the techniques he is using to sustain the attention of his readers/listeners and to make the lessons of conduct more effective. He makes the recipients of his sermons aware that he knows that they want "[ $t$ ]o get into mens affections" (Fordyce, Sermon II, 32, spelling original), and that there is no shame in this. But even for this they need guidance and he can, despite his so-

At one point in his sermons he hopefully declares: "[you] have been addressed in the style of love and admiration. I have taken the liberty to address you in that of zeal and friendship; a style not the less sincere, or less worthy of your attention, for being sober and impartial. ... Suppose me speaking of you as a brother" (Fordyce, Sermon III, 44). 
cial position, teach them how to "captivate most, and please longest" (Fordyce, Sermon II, 42). As such, he not only re-instates his authority in knowing what men want, but he is also more than ready to divulge all the secrets of the members of his sex. While he advises women to understand men's needs and desires, he likewise claims that "[t]he male heart is a study, in which your [female] sex are supposed to be a good deal conversant" (Fordyce, Sermon II, 32). By no means is he claiming that men are angelic; on the contrary, he discusses all the ways and means that men use to corrupt women in his sermons. He also admits the knowledge of double-standards on which society is built. Still building the rapport and trust between himself and his readers/listeners, he posits: "The world, I know not how, overlooks in our sex a thousand irregularities, which it never forgives in yours" (Fordyce, Sermon I, 17) and "In our sex the character of being lost to shame is scandalous; but in yours - who can describe the detestation it excites?" (Fordyce, Sermon III, 52). In such a reality, no matter how unfair it may seem, women need to fight against mistreatment and misinterpretation, but only by means of being exactly what is expected of them. The strict decorum which Fordyce subsequently presents and discusses needs to be supported by constant self-vigilance. The preacher makes it even more daunting than Tague (2002: 22) suggests in her study, because it is not only that women have to check themselves at every step, but the entire world has its eyes on them as well. Fordyce politely warns: “... I say, that the men you marry, the children you bring, and the community at large, will be all deeply interested in your conduct" (Fordyce, Sermon I, 23). And the negative evaluation by these individuals is the greatest punishment a woman can expect. As Michel Foucault proved in the Spectacle of the Scaffold (1977), one does need to use continued and overt displays of violence to punish the transgressor of normativity; there are more bloodless ways of ensuring compliance.

One of the repeatedly stressed consequences of misbehaviour and transgression against the rules of propriety in conduct texts for women is the loss of good reputation. Fordyce reminds: "Remember how tender a thing a woman's reputation is, how hard to preserve, and when lost how impossible to recover" (Fordyce, Sermon II, 28). Just like many other eighteenth-century moralists, the preacher seems to suggest that because feminine virtue is innate, it takes effort to ruin such God/nature-given gift; therefore, the fault is entirely women's, and this despite his earlier negative comments about some men making them their prey. Women who cannot recognize signs of depravity in men or, worse, women who enjoy a frivolous life themselves are purposefully putting themselves at risk. And no surprise then that due to such women men are tempted to suspect "the sex are all of a piece" (Fordyce, Sermon I, 22). It is therefore a woman's task not only to make sure that she avoids all rogues, but also that she investigates her own behaviour for the signs of encouraging depravity. Since it 
is humility and modesty, which is expected of women (and Christians in general) which they need for such self-examination and self-policing, Fordyce reflects by means of a rhetorical question: "Is there nothing in your own minds that whispers the frailty of your sex?" (Fordyce, Sermon III, 46). For the preacher the answer is obvious as he has already established in his sermons the true nature of the female-kind. What women need to do, then, is to make their virtues not only their guidelines in every day behaviour but also to make sure that their virtuous conduct does not look like it is enforced or just a façade. Fordyce advice on this is: "By being what you ought to appear, you will be under no temptation of appearing what you are not" (Fordyce, Sermon XIV, 206). The outer self should reflect the inner, and thus men, or society in general, will be able to effectively and successfully decode a woman's nature and character. What should be noted here is that manuals of conduct of any kind do not let their readers dwell on generalities in terms of advice on conduct. They offer examples and make sure that they are comprehensive, even if they take the form of an exemplum or anecdote. Fordyce, already skilled in interpreting dogmas and religious precepts, likewise does not leave his fair sisters in the dark about which virtues are expected in/of them.

Studying the history of books for women, Suzanne W. Hull styled the title of her publication after the three most often preached feminine virtues: chastity, silence, and obedience. ${ }^{6}$ While her research finishes with 1640 s, these virtues reappear in later manuals. Fordyce, superficially at least, seems to differ. He is not promoting virginity; he does not discuss unconditional obedience (apart from obeying the parents and God); and even silence is good but only when there is nothing important one has to say. However, he manages to convey the same lessons as his predecessors by preaching modesty, shamefacedness, meekness and sobriety. Using the Bible, the writings of the Apostles but also the Puritan Christian allegory by John Milton and the novelistic lessons on femininity by Samuel Richardson, Fordyce preaches that virtue "loves the shade" and that "[t]he retiring graces have been always the most attractive" in a woman (Fordyce, Sermon III, 49). In a nutshell, then, for Fordyce shamefacedness is "an ornament necessary and wise" (Fordyce, Sermon III, 45); sobriety "is a sort of vesture entirely void of show" (Fordyce, Sermon IV, 60); and meekness becomes "a timidity peculiar to your sex" (Fordyce, Sermon XIII, 161). As such, the virtues he places as first in his sermons are indeed ones that guarantee reserve and restraint, and also require from women to curb their passion. Meekness in particular is becoming for women and testifies to their love of God. More importantly, it also indicates their acceptance of the assigned

$6 \quad$ See Suzanne W. Hull. 1988. Chaste, silent \& obedient: English books for women: 1475-1640. San Marino: Kingsport Press. 
position in society. It likewise proves female worth, if practiced well because, as Fordyce states, "[m]eekness, cultivated on Christian principles, is the proper consummation, and highest shinning, of female excellence" (Fordyce, Sermon $X I I I, 160)$. Importantly, however, he does not see it as a female virtue only, but only in terms of religious behaviour. In any other circumstance in life there is too big a divide between female and masculine experience and lifestyle, and men cannot be too meek in their public actions. ${ }^{7}$ As such, women not only do not need certain traits of character but they also face fewer temptations in life.

The fact of limited exposure to the enormous repertoire of temptation is also connected with women's designation to the private sphere, instead of the public one. Such enclosure, though not imprisonment as Fordyce seems to hint, is beneficial for women's development and reputation. Echoing medieval warnings about the dangers of being seen or participating too much in the activities offered by the outside world, Fordyce convinces his listeners/readers that the domestic sphere is the most proper one for women. Cautioning that "the majesty of the sex is sure to suffer by being seen too frequently, and too familiarly" (Fordyce, Sermon III, 54), he advises looking for happiness within the domestic realm and its duties. Therein, a modest, and, due to the lack of exposure, a chaste woman, can feel secure and practice her excellence. Naturally, Fordyce does take into consideration that some women, due to their class, will be willing or even have to step outside their households, but then they need to be checking their comportment even more than others. Like many authors of manuals he presents some ground rules pertaining to social interaction, which requires not only the awareness of rules of politeness but also techniques of autopresentation. This is of particular importance for unmarried ladies, especially those looking for proper candidates for a husband. Once again Fordyce's knowledge of a man's psyche proves useful in guiding his readers/listeners.

Throughout the two volumes the preacher offers insights into how men perceive and interpret female behaviour and looks. With an almost generic set of lessons of dress and make-up, he likewise reveals what men desire in the women they want to marry, in contrast to those with whom they want to have a good time during parties but secretly despise. Fordyce acknowledges the power of appearances but warns that it is not long-lasting, and men's acute minds will notice the incompatibility with what the woman seems to be and what she really represents. So men may be temporarily bedazzled, and even enjoy an extravagant woman's company for a while, but in reality they are looking for some-

7 For the sake of a more convincing exposition of such an argument, Fordyce explains: "Their [men's] Constitution of mind, no less than of body, is for most part hardy and rough. By means of both, by the demands of life, and by the impulse of passion, they are engaged in a vast diversity of pursuits, from which your sex are precluded by decorum, by softness, and by fear" (Fordyce, Sermon $V, 79$ ). 
thing else. Fordyce reveals that men fall for: "women well bred and sober minded at the same time, of a cheerful temper with sedate manners; women, of whom they may hope that they will love home[,] be attracted to their husbands, attentive to their families, reasonable in their wishes, moderate in their expenses, and not devoted to eternal show" (Fordyce, Sermon III, 56, original spelling). As such, they will appreciate a virtuous woman who likewise proves to possess what Fordyce calls female accomplishments in three areas: "Domestic, Elegant and Mental" (Fordyce, Sermon VII, 97). There should be no doubt, however, that it is the first type that they seek in a woman. The latter, connected to women's intelligence, are the most difficult to advertise well.

While feminist and literary historians notice the more benevolent attitude toward female education, and indeed history proves that female participation in the intellectual sphere was on the rise in this century, conduct texts for women caution about scaring men off with intelligence. A male interlocutor should easily notice that he is dealing with an intelligent woman but he must not feel threatened or belittled by it. As one can read between the lines in Fordyce's sermons, men experience such humiliation from other men, so they do not want to feel such discomfort while interacting with women. When touching upon the topic of clever women and men's negative reaction to them, Fordyce explains: "You will probably tell me, they were afraid of being outshone; and some perhaps might be so. ... Men who understand the science of domestic happiness, know that its very first principle is ease. ... We are never safe in the company of a critic ..." (Fordyce, Sermon V, 90-91). While the preacher's contemporary, Thomas Marriott (1759: 229), advised women to allow their men to feel like the "Master of the Field", Fordyce, knowing that they are not, himself politely calls for genuine acceptance of masculine superiority in such matters. Additionally, he uses the arguments with which protofeminists, such as Mary Astell and Mary Wollstonecraft, disagreed and fought against, namely that too much intelligence in a woman leads to the annihilation of feminine graces. Fordyce explains in a confessional mode: "I should be afraid, lest the sex should lose in softness what they gained in force; and lest the pursuit of such elevation should interfere a little with the plain duties and humble virtues of life" (Fordyce, Sermon V, 9495 , spelling original). So while men can imagine a life with a woman who lacks in education, they will not accept one who lacks softness, modesty and meek submission. Fordyce authoritatively states: "These the men are taught by nature, by education, and by custom, to consider as your duty, and their right; neither will they be easily brought to dispense with it" (Fordyce, Sermon XIII, 184). Since women are not able to change such masculine socialisation, they should try to find happiness within the patriarchal boundaries put up on their character.

In conclusion, Fordyce's sermon manual offers its female readers/listeners clear guidelines on how to lead a successful life within the ideological bounda- 
ries of the eighteenth century. However, he seems to be aware of the fact that what he discloses might be difficult to accept and, at times, may seem harsh. Yet, as he warns, his wish is not to flatter or lie, so there is likewise no need for him to hide the undeniable fact that "most men expect too much from the women they marry" (Fordyce, Sermon XIV, 191). Moreover, since the world is generally built on similarly unfair expectations concerning women, as Fordyce proved discussing the double standards observed in the eighteenth century, learning to accept it and, in a way, negotiate with the demands could potentially make a woman's life easier. As such, meekness, modesty, sobriety, prudence and excellence in domestic accomplishments, which he advocates on the pages of his Sermons to Young Women, not only guarantee a sense of women's selffulfilment but they also help to seduce the eighteenth-century man of sensibility who will truly appreciate such a virtuous woman. Finally, to seal up his collection of sermons, Fordyce terminates his sermons with the powerful "Amen", which, although expected in a sermon, serves a far greater purpose. The religious "Amen", simultaneously, prevents any form of disagreement on the part of the fair listeners/readers and voices a wish - "so be it" - on behalf of men. As a result, Fordyce manages to issue a religious and, at the same time, an almost paternal call to young eighteenth-century ladies who not only wish to enjoy the heavenly bliss after death but, in particular, want to be appreciated as perfect women by their society, and especially by men.

\section{REFERENCES}

Arditi, Jorge. 1998. A genealogy of manners: Transformations of social relations in France and England from the fourteenth to the eighteenth century. Chicago and London: The University of Chicago Press.

Armstrong, Nancy and Leonard Tannenhouse (eds.). 1987. The ideology of conduct: Essays in literature and the history of sexuality. New York and London: Methuen.

Barker-Benfield, G. J. 1996. The culture of sensibility: Sex and society in eighteenth-century Britain. Chicago and London: The University of Chicago Press.

Fordyce, James. 1766. Sermons to young women. In Two Volumes, vol. I, $6^{\text {th }}$ edn. London: Printed for D. Payne.

Fordyce, James. 1767. Sermons to young women in two volumes, vol. II, $6^{\text {th }}$ edn. Dublin: Printed for J. Williams.

Foucault, Michel. 1977. The spectacle of the scaffold. London: Penguin Group.

Hull, Suzanne W. 1988. Chaste, silent \& obedient: English books for women: 1475-1640. San Marino: Kingsport Press.

Jones, Vivien (ed.). 1995. The young lady's pocket library, or Parental monitor, with a new introduction by Vivien Jones. Bristol: Thoemmes Press. 
Jones, Vivien. 1997. Women in the eighteenth century: Constructions of femininity. London and New York: Routledge.

Marriott, Thomas. 1759. Female conduct: Being an essay on the art of pleasing to be practised by the fair sex, before, and after marriage. A poem in two books. Humbly dedicated, to Her Royal Highness, The Princess of Wales. Inscribed to Plautilla. London: Printed for W. Owen, at Homer's Head, Temple Bar.

Miles, Margaret R. 1991. Carnal knowing. Female nakedness and religious meaning in the Christian West. New York: Vintage Books.

Newton, Sarah E. 1994. Learning to behave: A guide to American conduct books before 1900. Westport, CT: Greenwood Press.

O'Brien, Karen. 2010. Women and the Enlightenment in eighteenth-century Britain. Cambridge: Cambridge University Press.

Tague, Ingrid H. 2002. Women of quality: Accepting and contesting ideals of femininity in England, 1690-1760. Woodbridge: The Boydell Press.

Vickery, Amanda. 1999. The gentleman's daughter: Women's lives in Georgian England. New Haven and London: Yale University Press. 